\title{
Effect of polyethylene mulch on soil temperature
}

\author{
G. A. KAYANDE , M. U. KALE, S. B. WADATKAR, M. M. DESHMUKH, A. S. TALOKAR AND S. K. UPADHYE
}

Received : 25.07.2016; Revised : 28.10.2016; Accepted : 21.11.2016

\section{MEMBERS OF RESEARCH FORUM:}

Corresponding author :

M.U. KALE, Department of

Irrigation and Drainage Engineering,

Dr. Panjabrao Deshmukh Krishi

Vidyapeeth, AKOLA (M.S.) INDIA

Email: kale921@gmail.com

\section{Co-authors :}

G. A. KAYANDE, S. B. WADATKAR, M. M. DESHMUKH AND A.S. TALOKAR,Department of Irrigation and Drainage Engineering, Dr. Panjabrao Deshmukh Krishi Vidyapeeth, AKOLA (M.S.) INDIA

S.K. UPADHYE, Department of Soil and Water Conservation Engineering, Dr. Panjabrao Deshmukh Krishi Vidyapeeth, AKOLA (M.S.) INDIA

Email: suhasupadhye1976@ gamil.com

\section{Summary}

Field experiment framed in a Randomized Block Design was conducted to assess the impact of polyethylene mulch on soil temperature and yield of drip irrigated bitter gourd during 2015-16 in the Department of Irrigation and Drainage Engineering Dr. PDKV, Akola. The soil temperature at $15 \mathrm{~cm}$ soil depth at 06:00 hrs was observed more than the ambient temperature, while at 14:00 $\mathrm{hrs}$, it was less than ambient temperature, irrespective of irrigation scheduling treatments. The soil temperature under black mulch was observed to be highest followed by silver mulch, while temperature of soil without mulch cover was observed to be the lowest. Though average ambient temperature varied from 13 to $32.1^{\circ} \mathrm{C}$, the soil temperature under mulch varied from 22.4 to $27.8^{\circ} \mathrm{C}$ i.e. in optimal temperature range for bitter gourd production. Subsequently, the crop yield was found maximum under black polyethylene mulch with irrigation scheduling at 80 per cent crop evapotranspiration through drip irrigation system followed by under silver mulch with irrigation scheduling at 80 per cent ETc.

Key words : Bitter gourd, Mulch, Drip irrigation, Soil temperature, WUE

How to cite this article : Kayande, G. A., Kale, M. U., Wadatkar, S. B., Deshmukh, M. M., Talokar, A. S. and Upadhye, S.K. (2016).Effect of polyethylene mulch on soil temperature. Asian J. Soil Sci., 11 (2) : 332-336 : DOI : 10.15740/HAS/AJSS/11.2/332-336. 